\title{
'A Living Thing': \\ The Whakakotahitanga Flagstaff and its Place in New Zealand History
}

VINCENT O'MALLEY

The story of Hone Heke's successful efforts in felling the flagstaff upon Maiki Hill at Kororareka four times between July 1844 and March 1845 - the fourth occasion marking the start of the Northern War between the British with their Maori allies and Heke's followers - is widely known. ${ }^{1}$ The fate of the flagstaff after the war came to an inconclusive end at Ruapekapeka in January 1846 is, however, less appreciated. Yet the flagstaff's subsequent history reveals just as much about the broader relationship between northern Maori and the Crown as the events upon Maiki Hill between 1844 and 1845 disclose about the breakdown in that relationship.

Throughout the period between 1846 and 1857, Ngapuhi leaders at various times proposed to re-erect a flagstaff. Their suggestions met with at best lukewarm support from Crown officials, who worried that, regardless of who erected the flagstaff, the Crown would ultimately be required to defend it. Hence, when the pou kara known as Whakakotahitanga was erected on Maiki Hill in January 1858, Crown assistance was minimal. The decision to erect the new flagstaff had been made solely by northern Maori and was intended as an emblem of reconciliation and unity in the wake of the Northern War. These sentiments were scarcely reciprocated. Crown officials remained apprehensive about the strength of northern Maori 'attachment' to the government and feared that the flagstaff might again become a source of trouble and unrest. Later, as the government gradually gained a firmer grip over the north, such fears were put to bed. Unfortunately, the government's more complacent attitude meant that Whakakotahitanga could be largely neglected, forgotten and sometimes abused. Against the odds, Whakakotahitanga has endured and remains a taonga of national significance, despite the lack of official recognition of its status in various ways.

Conventional accounts of the Northern War at one time praised Governor George Grey for his wisdom in not insisting that the flagstaff be re-erected on Maiki Hill, thereby not putting Heke to open shame. ${ }^{2}$ Grey's decision was no doubt a wise one, but it had another motivation, to prevent further Crown humiliation. If the symbol of British sovereignty in the north were toppled again, Grey would be obliged to take action against the offenders, 
exposing the weakness of the Crown's position - and the lie of its victory in the Northern War - for all to see. ${ }^{3}$ Grey could live without this pitfall, even if it rankled with those few Europeans still resident in the north. As Henry Williams observed four months after Ruapekapeka: 'The flag-staff in the Bay is still prostrate, and the natives here rule. These are humiliating facts to the proud Englishman, many of whom thought they could govern by a mere name. ${ }^{4}$

In fact, a new flagstaff had been erected on Maiki Hill, overlooking the township of Kororareka or Russell (as it was now called by Pakeha), as early as 7 February 1846. Two days later the local commanding officer reported that it was 'still standing', suggesting that even he was a little surprised. ${ }^{5}$ Tamati Waka Nene, who had chosen to re-erect the flagstaff and fly a red ensign from it on his own initiative, explained that his actions were not intended as a provocative gesture, but symbolised his 'loyalty'. ${ }^{6}$ Although the remaining British troops in the Bay were quickly moved from Waitangi to Kororareka to defend the new flagstaff, ${ }^{7}$ this reassignment was no more than an interim measure. Nene was quietly prevailed upon soon after to remove the flagstaff until the government could erect and defend an official one. ${ }^{8}$ It never did.

According to Protector of Aborigines Edward Shortland, the earlier flagstaff had been viewed as a kind of pou rahui, symbolising not just British claims to sovereignty, but British claims to the land itself. In this context, the expected response was to take it down to challenge the ownership claim. The flagstaff's function as a pou rahui helps to explain both Heke's view that it was not his felling of the flagstaff that had caused the war but the Crown's persistence in re-erecting it and his later repeated offers to re-erect the flagstaff himself, or to do so jointly with the governor. ${ }^{9}$ Any unilateral re-erection of the flagstaff by the Crown, viewed from this perspective, could hardly fail to bring about further trouble in the north, whereas a joint initiative to restore it, or even a purely Maori one, would be interpreted quite differently as upholding and acknowledging the mana of northern Maori.

The aged chief Kawiti in 1847 initiated the next effort to rear the flagstaff on Maiki Hill. Three spars had been harvested for the purpose, and Heke had been informed of the proposals, reportedly replying that Kawiti "may do so if he thinks proper'. ${ }^{10}$ By early November 1847 the spars had been hauled on to the beach at Russell, and local Maori were busily squaring them and reducing them to their proper size. Cyprian Bridge, the Russell Resident Magistrate, informed Kawiti, Waka Nene, Pomare and other chiefs that Governor Grey 'had no objection to their re-erecting the Flag-Staff' and that he would meet their request for ropes with which to haul the spars up the steep hill, sending the necessary supplies on the government brig by 'the first opportunity.' ${ }^{11}$ The brig must have had an exceptionally busy next 
three months, because at the end of January 1848 Bridge wrote again to the Colonial Secretary, this time to register that the chiefs had 'expressed much disappointment' at the failure to provided the promised materials, as a consequence of which the flagstaff remained on the beach. ${ }^{12}$

Bridge believed Wahapu would be the preferable spot for a flagstaff so long as the remaining British troops at the Bay of Islands were stationed there. Grey, though, stonewalled the initiative, declaring that he saw 'no good reason for issuing orders on the subject'. ${ }^{13}$ Confronted with direct requests from the chiefs on his previous visits to the Bay, Grey had been left with little option but to offer the requested assistance - to do otherwise would be to look weak and insecure. Yet at the same time he realised that, regardless of who put the flagstaff up, its defence would become a matter for the Crown. For Grey, even the insurance offered by Kawiti's personal involvement in the re-erection plan (which would almost certainly oblige him to defend the flagstaff in future) and Heke's apparent lack of concern over the whole affair did not sufficiently mitigate the risks. Maiki Hill thus remained bereft of a flagstaff for the next decade.

In the mid-1850s the Crown began to contemplate removing the remaining troops from the Bay of Islands. Willingness to consider such a measure was prompted not by a belief that their presence was no longer necessary but rather by the realisation that 122 soldiers could, of themselves, neither offer an effective deterrent to further unrest nor quell it without reinforcement from Auckland. ${ }^{14}$

Even though the decision had been purely a tactical one, the removal of the last remaining troops from the Bay of Islands - completed early in 1858 but debated openly for several years prior - was welcomed as a positive development by northern chiefs, who now assumed an added responsibility for keeping the peace in the area. James Clendon reported that the 'loyalist' rangatira Tamati Waka Nene was 'delighted that so much confidence will be placed in him'. When Clendon informed Nene that the governor now looked upon the Assessors in the north as his soldiers, 'the old fellow was almost mad with joy'. ${ }^{15}$

In the wake of the Northern War, the government had more or less turned its back on the north, whose local economy continued to stagnate. The removal of the troops was one sign of a thawing in relations, but while northern Maori sought to revive their economic fortunes by forging a closer relationship with the Crown, officials had their own reason for again showing an interest in the north. Following the emergence of the Kingitanga in the central North Island, a primary preoccupation of many officials and politicians, as expressed by Hugh Carleton in 1858, was 'securing their rear ... obtaining a safe country to fall back upon ... [and] not leaving Auckland between two fires' ${ }^{16}$ If the northern iwi made common cause 
with the Waikato tribes, then Auckland would effectively be besieged. As officials in the north continued to nervously remind their superiors, given strong whakapapa connections, an alliance of this kind was not beyond the realms of possibility. ${ }^{17}$

Such fears persisted long after northern Maori had renewed their Treaty relationship with the Crown and erected Whakakotahitanga as a symbol of the re-affirmed union. In fact, emissaries from the Kingitanga had provided the immediate catalyst for the flagstaff. According to Henry Williams, a visiting Kingitanga deputation was informed in response to their request for support that northern Maori would acknowledge no other sovereign than Queen Victoria. Northern rangatira determined forthwith to form a council for the restoration of the flagstaff on Maiki Hill. ${ }^{18}$ The Hokianga chief Mohi Tawhai told Governor Thomas Gore Browne in July 1857 that a number of key rangatira had convened a hui at Kororareka 'on account of our having heard that the natives of the south had proclaimed a king' and had resolved that the new flagstaff should be the only 'King the Ngapuhi acknowledge'. ${ }^{19}$

The final decision to re-erect the flagstaff appears to have been made with widespread endorsement from the northern tribes sometime between October and November 1857. According to Maihi Paraone Kawiti, son of the late chief Kawiti, some 1379 individuals and 32 hapu had consented to the proposal to re-erect the flagstaff on Maiki Hill, subscribing over $£ 86$ to a fund to pay the costs involved in doing so. ${ }^{20}$ Kawiti himself later recalled that he had overseen the entire operation, from the selection and felling of the tree to its preparation and transportation to Russell and the payment of $£ 100$ to carpenters to finish off the work. ${ }^{21}$

According to Russell Harbour Master Edward Bolger, between 200 and 300 Maori had been present to assist with extracting the spar from the bush, Bolger adding that "the only jealousy that appears about the "Flagg [sic] Staff" now is, that all hands want the honour of pulling it up'. Kawiti had applied to him for rope, blocks and other equipment of the kind Grey had refused to send a decade earlier, and Bolger had sensibly complied with the request. ${ }^{22}$ The wily Native Secretary Donald McLean successfully argued that food supplies to the value of $£ 20$ should also be sent to those hauling the spar out, noting that the feeling in favour of re-erecting the flagstaff was 'very general' and it was unlikely to meet with opposition from any northern chiefs. ${ }^{23}$

Yet beyond a few bags of flour and sugar for those involved, the government was decidedly twitchy about openly providing support for the re-erection of the flagstaff. The government's skittishness emerged most clearly at Mangonui, where the decision had also been made to erect a flagstaff as a symbol of the renewed relationship between local Maori and 
the Crown. ${ }^{24}$ Local Resident Magistrate W.B. White reported that the tribes sought a flagstaff at Mangonui 'that they might show themselves to the world as the upholders of the law, and its officers' ${ }^{25}$ Despite their declared allegiance, his request for an actual flag to hoist, once the flagstaff was ready, encountered opposition from the Native Minister, C.W. Richmond, who considered: '[it would be] inexpedient to make a present [of a] flag to the Monganui [sic] Natives. A similar present could be then expected at the Bay which would have the effect of constituting the new Flagstaff at Kororareka Crown property. This I think would be highly inadvisable. ${ }^{26}$

The old concern - which had left Grey too afraid even to send Kawiti a few bits of rope a decade earlier - had revived, namely defending the flagstaff once it flew the Union Jack. T.H. Smith, the Assistant Native Secretary, pointed out, however, that it had always been Crown policy to provide flags when requested unless special grounds for refusal existed, adding:

The case of the Bay of Islands is scarcely parallel. The erection of the flagstaff there is intended as an acknowledgement of a past error $\&$ an attempt to repair it $\&$ should therefore be distinctly shown to be spontaneous and should be done without assistance or cooperation on the part of the Govt. A refusal in the present instance would I am inclined to think be injudicious \& tend to check the sentiments of loyalty \& good feeling towards the Govt. which has recently been so warmly expressed by the Natives at Mangonui. ${ }^{27}$

Mangonui Maori accordingly got their requested flag, although somewhat ludicrously, it was to be given 'as a present from the magistrate, rather than from the Queen, who should not be supposed to have a Flag flying where H.M. has no force at hand to protect it'. ${ }^{28}$ The supposedly 'pacified' north was not yet safe enough.

All eyes looked to the Bay of Islands, however, and it was there that on 29 January 1858 the northern iwi erected their new 'King'. Some 95 feet long and 2 feet in diameter, the spar used for the new flagstaff required more than 500 men to carry it up Maiki Hill..$^{29}$ According to the brief account of the ceremony published in Te Karere Maori, the assembled rangatira had unanimously declared that the new flagstaff should be called 'Our union with the Laws of the Queen' [Ko te whakakotahitanga ki nga ture o Kuini]. ${ }^{30}$ Yet it is interesting to note that Kawiti himself many years later explained its name quite differently, informing the governor that 'Te Whakakotahitanga' stood for the union of the two peoples, Maori and Pakeha. ${ }^{31}$ It was not intended, in other words, as a symbol of Ngapuhi's subjugation to English law but rather to mark their commitment to a renewed relationship of mutual benefit with the Crown and settlers.

It was all the more ironic, then, that the only apparently sour note to proceedings was that Governor Browne was not present to hear these 
expressions of goodwill or to participate in the ceremony itself, even though he had been at the Bay just a few days earlier meeting with northern chiefs. Browne informed McLean that he had heard that 'Kawiti's people were much disgusted at my not landing a second time to share in the hoisting [of] the Flag there'. ${ }^{32}$ His decision not to attend, Browne wrote defensively, 'had nothing to do with fatigue' but was the result of 'careful consideration \& consultation' with T.H. Smith. In a separate letter, Browne revealed the real reason for his decision, writing that he was 'very sorry not to take part in the erection of the flag at Kororarika [sic] but Smith and Clendon were very decided in advising me to the contrary and I felt that it would not be wise to commit myself to a party who might change their mind and throw down the flag as quickly as they raised it'. ${ }^{33}$

Browne was almost entirely dependent on McLean for what little knowledge he possessed of things Maori. Had McLean been present, he might well have advised that a flagstaff erected with the widespread support of northern iwi would not lightly be attacked. Such an attack would likely be perceived as a slight on the mana of those who had participated in the event and a challenge to the renewed alliance of friendship and support with the Crown. Kawiti, in fact, sought the formal appointment of kaitiaki (guardians) charged especially with taking charge of the flagstaff. Smith recommended that 'a desirable arrangement would appear to be to commit the Flagstaff to the joint custody of two or more chiefs chosen from those who supported and those who resisted the Government in the war in the North'. ${ }^{34}$ It would appear that he may have had in mind Kawiti himself along with Tamati Waka Nene, though whether any formal appointments were made remains unknown.

In the 1840s northern Maori and the Crown had gone to war over (according to Heke's account) the latter's insistence on re-erecting the flagstaff unilaterally. ${ }^{35}$ In 1858 the Crown remained desperate to avoid any involvement in its re-erection that might oblige it to defend Maiki Hill. Perhaps four failures were seen as enough, but it was a measure of how nervously the Crown looked upon the north, even more than a decade later, that officials continued to lack confidence in their ability to successfully defend the flagstaff there and remained suspicious of the overt statements of loyalty and friendship expressed by northern Maori. In fact, when Governor Browne visited the north he feigned perfect indifference to the flagstaff, telling the chiefs:

If the hands which cut it down wish to replace it, it is well. As an acknowledgement to the world of a past error, it is well. Whether it be replaced or not, the sovereignty of the Queen over this island remains the same: the Queen is Queen of New Zealand whether all her subjects know her as such or not. Those who are ignorant will grow wiser in time. 
The flag is but a symbol. The Ngapuhi once mistook it for the symbol of a power to be used to injure them and cut it down. Strife ensued and blood was spilt. The Queen was grieved that men's lives should be sacrificed through a misunderstanding. She directed that forbearance should be shewn and that the Ngapuhi should be left to find out their error. The flagstaff was not again set up. Those who cut it down have now seen their error. The Ngapuhi now know that the flag was a symbol of a power which has ever been used for their protection and benefit. ${ }^{36}$

Browne's statement that the flag was 'but a symbol' sounds an ironic note: critics at the time viewed Browne as inclined to read rather too much into symbolism and labels (specifically, in his insistence that there could be no such title as 'King' held by a Maori chief). Symbols mattered - probably to the pompous and aristocratic Browne more than most - and it was stretching the old maxim about making a virtue out of necessity just a little too far to assert that the Crown had not re-erected the flagstaff so that Ngapuhi could be left to find out the error of their ways alone. The Crown had not replaced the flagstaff again simply because its grasp on the area remained tenuous. Now that northern Maori had taken matters into their own hands, Browne and other officials pretended not to care, hoping that this indifference would excuse them from having to defend the flagstaff in the event of further trouble in the north. The psychic scars left by Hone Heke thus continued to haunt officials in the north long after the chief's death. The Queen, however, gamely expressed her 'satisfaction' at the restoration of the flagstaff. ${ }^{37}$ That was more than most local officials could bring themselves to do.

For Ngapuhi, Whakakotahitanga became a symbol of reconciliation and unity, as tribal representatives explained at the Kohimarama conference in 1860 and on numerous other occasions. ${ }^{38}$ Crown officials held an altogether more ambivalent view of their relationship with northern Maori. But in the tense atmosphere that predominated in the period immediately prior to the outbreak of the Waikato War, support from the northern tribes was deemed crucial, and for a time some sensitivity was apparent. In late April 1863 the Russell Resident Magistrate, R.C. Barstow, informed Civil Commissioner George Clarke Senior:

The rigging of the flagstaff erected by the Ngapuhi about five years ago as an emblem of their perfect reconciliation with Her Majesty's Government is at present in a very bad state, no attempt ever having been made to keep it in repair: the lanyards of the stays are rotten and parted, and the stays themselves decaying from want of a little tar. As great mortification would be felt at the fall of the flagstaff (which cost the natives some $£ 130$ in money to erect) and unpleasant consequences might follow I deem it my duty to bring the matter to your notice . . . . ${ }^{39}$ 
Barstow estimated that an immediate outlay of $£ 5$ would suffice to repair the rigging, with a similar amount required to paint the flagstaff itself. Within days he had received authorisation from the Colonial Secretary's office to incur the expenses necessary to repair the flagstaff and had been instructed to ensure the work was properly performed. ${ }^{40}$

Barstow may have been concerned that if the flagstaff accidentally fell this might have been taken as a tohu (sign) by Ngapuhi that their firm expressions of 'loyalty' to the Crown, symbolised by the re-erection of the flagstaff in 1858 , were misplaced. At a time when officials remained anxious about the allegiance of northern Maori, and were desperate to avoid a war on two fronts at all costs, this prospect was sufficient to ensure apparently prompt attention to Whakakotahitanga. Subsequent events proved the government's anxiety justified. In September 1864, for example, 220 Waikato Maori held prisoner on Kawau Island, in the Hauraki Gulf, escaped to the Mahurangi district with the reported assistance of local Ngapuhi sympathisers. ${ }^{41}$ At no point during the 1860 s were Crown officials ever entirely confident about the ongoing allegiance of the northern tribes. Under the circumstances, small gestures such as repairs to the flagstaff must have seemed like smart investments.

Security concerns waned gradually, as increased European settlement and land alienation gave the Crown a firmer grip on Northland. The Whakakotahitanga flagstaff thus entered a long period of neglect, though not without occasional complaint from northern Maori. In March 1873 the unveiling of a monument to the late chief Tamati Waka Nene was accompanied by a meeting between Native Minister Donald McLean and northern rangatira. Maihi Paraone Kawiti, the rangatira most closely associated with the re-erection of the flagstaff, told McLean that Whakakotahitanga stood:

... in token of the submission and reconciliation of the tribes which had been led by his late father, and who, in connection with Honi [sic] Heke, had cut down the original staff. He urged that as the staff had been put up by him at some pains and trouble, and as an earnest of the future good behaviour of all those who were engaged in the native rebellion. [sic] The Government might in their turn have accepted the offering, and preserved the flag upon it which was to have been the symbol of the Queen's authority; and that, in short, the Government should clothe the flagstaff. ${ }^{42}$

McLean told Kawiti that 'in reply to the request that the flag might be taken care of and respected, he would order that for the future the flagstaff should be decorated at stated times'.

For Kawiti the concern was thus not solely to maintain the physical condition of the pou kara but also to ensure that the mana of the flagstaff, 
and the mana of those who had made the momentous decision to erect it, were suitably acknowledged. McLean's response indicated that he clearly understood and appreciated the importance attached to this issue.

Later officials were often less appreciative of the history and symbolic significance attached to Whakakotahitanga, though this did not prevent Kawiti from attempting to educate them on these points on many occasions. In 1888, for example, shortly before his death and towards the end of a long and unsuccessful campaign to gain redress for lands Kawiti felt had wrongly been taken from him, the rangatira informed the governor:

I have been making applications year after year to the Government since Mr. Donald McLean's time, and this in consequence of the suffering which I experienced at the hands of the Govt. - who are oppressing me. They did not consider and recognise that it was I who restored to Her Majesty the Queen the "mana" of her sovereignty when Hone Heke cut down her flagstaff at the Bay of Islands and that it was I who carried out everything in connection with the setting up of the flag staff, paying the carpenter $£ 100$.

I also restored the flag staff and all its requisites to Governor Browne free of cost after that I gave my land away as a gift in honour of the occasion of the restoration of the flagstaff - it also signify [sic], according to the Maori custom, the establishment of peace and a sign of respect for the Queen - and peace to both man and the land, consequently that flag was named "Te Whakakotahitanga" (the Union) of the two races, Pakeha \& Maori. ${ }^{43}$

Kawiti's complaints this time were ignored, just as Whakakotahitanga itself was neglected. Unlike the Treaty parchment, it was not, at least as far as we know, nibbled away at by rats, but was instead put to utilitarian purposes as a shipping signal station, before falling victim to a disastrous gorse fire in February 1913. ${ }^{44}$ Although the charred remains were repaired, the flagstaff was considerably shorter when it was subsequently re-erected, minus the former topmast and crossbar. ${ }^{45}$

Then, in 1930, the flagstaff again garnered attention when a plaque specially donated for the occasion was unveiled. Frank Acheson, the outspoken Native Land Court judge based in the north, had been asked by the Russell Town Board in February 1930 to organise the ceremony and coordinate with local Maori. ${ }^{46} \mathrm{He}$ reported back the following month that he had held several meetings with interested Maori, who looked with great favour on the proposed memorial tablet but had 'decided to alter the word rebel to Maori'. ${ }^{47}$ The Russell Town Board resolved to hold the unveiling ceremony on 9 April 1930, a date without any obvious significance in the history of the flagstaff. 
The tablet was unveiled before a large crowd of assembled Maori and Pakeha by Acheson and Kirihi Te Riri Maihi Kawiti, the son of Maihi Paraone Kawiti and grandson of Kawiti. Whakakotahitanga was festooned with numerous colourful flags for the occasion, and a bullock was provided by the Town Board for the subsequent hangi held to celebrate the day's events. $^{48}$

Following this brief period of attention, the Maiki Hill site was leased for grazing purposes, despite being a scenic reserve. Although a condition of the lease was that the tenant should keep all noxious weeds and rabbits under control, the area surrounding the flagstaff was chronically overgrown with gorse. The Russell Town Board attempted gorse control and occasionally painted the flagstaff itself, but by 1939 gorse had become so rampant that the temporary grazing lease was cancelled due to the failure of the tenant to check its spread. ${ }^{49}$ A new lessee was encouraged to seek a government subsidy to assist with combating the problem, but by 1944 the latest lease had expired.

Only after the war did the poor condition of the flagstaff and its environs come to public attention. In 1948 the Russell Town Board informed the Internal Affairs Department that the flagstaff and surrounding scenic reserve was 'somewhat neglected'. ${ }^{50}$ A subsequent inspection conducted by the Senior Engineer from the Public Works depot at Okaihau confirmed that "the area surrounding the "flagstaff" is in a disgraceful condition, with gorse growing almost to the actual area on which the staff is erected'. He recommended that the area immediately surrounding the flagstaff be fenced off, that the path leading up to it (which had been damaged when a military road was constructed on Maiki Hill during wartime occupation of the area) be restored to a reasonable condition, and that funds be made available to assist the local gardening club with its plans to enhance the visual appeal of the area. ${ }^{51} \mathrm{~A} £ 50$ one-off grant and a $£ 5$ annual one were subsequently made for these purposes, and additional renovations to the actual flagstaff (painting and other repairs) were approved. ${ }^{52}$

The flagstaff, nearly a century old, and its gorse-prone surrounds were both in need of constant attention, however, and within less than four years both were again reportedly in poor condition. In March 1953 the DirectorGeneral of the Lands and Survey Department informed the Commissioner of Crown Lands in Auckland that 'this very important historic site and the surrounding reserve is very badly overrun with gorse and the enclosure around the flagstaff also requires attention'. ${ }^{53}$

By this time the flagstaff was no longer used to fly flags, and subsequent inquiries confirmed that it would need to be fitted with steel halyards before it could be put to use again. However, the area surrounding it remained overrun with gorse, and the Russell Town Board advised that it would be 
difficult to find anyone willing to graze stock on the reserve. ${ }^{54}$ Although the Board indicated that it was willing to assume responsibility for the flagstaff, its offer was in fact confined to the quarter-acre fenced area immediately surrounding Whakakotahitanga and did not include the wider gorse-infested surrounds. The Board had, on its own initiative, cleared the area and flown a flag on the occasion of the royal coronation and had since purchased a steel halyard with the intention of again flying the flag during Queen Elizabeth's visit to the Bay of Islands on 29 December $1953 .{ }^{55}$ The Department of Lands and Survey contributed $£ 5$ towards these costs. ${ }^{56}$

With rapid advances in noxious weed control in the post-war period, gorse no longer competed with apathy or ignorance as the main threats to the well being of Whakakotahitanga. Instead, two new hazards appeared on the scene for the first time: vandals and property developers. In a deeply ironic turn of events, given the previous history of the site, on the eve of Waitangi Day 1954, four drunken naval ratings (three of whom were Maori), attempted to fell Whakakotahitanga. Although the four men were apparently acting out an old naval joke, the results were serious for the flagstaff. Whakakotahitanga had an axe embedded in it when discovered in the early hours of 6 February, was badly gashed at its base - its 15 -inch diameter having been reduced to just six inches at the point of attack - and the steel halyards had been severed. Temporary metal sheathing was nevertheless placed around the damaged area, allowing a flag to be hoisted as planned on Waitangi Day. The four men were subsequently convicted, fined $£ 15$ each, and ordered to pay a further $£ 6.11 \mathrm{~s}$ in restitution. ${ }^{57}$

In 1955 the Russell Town Board proposed that the existing track to the flagstaff should be extended and improved so that visitors by car could drive right up to the summit. ${ }^{58}$ Although a shortage of funds meant that this plan was not immediately approved ${ }^{59}$ such developments would in the future inevitably change the appearance and nature of the hilltop that Whakakotahitanga had once dominated. Ironically, while local government officials conjured up new ways to make Maiki Hill an easier and more attractive destination for visitors, the flagstaff itself failed to receive urgently required attention.

By the early 1970s neglect had taken its toll on Whakakotahitanga. In 1973 visitors were encouraged to keep well away from the flagstaff after it was seen to be shaking violently in the wind. ${ }^{60}$ Its base was subsequently discovered to be rotting, and repairs shortened the once 95 feet pou kara to a little over 30 feet. ${ }^{61}$ Meanwhile, just as with the Treaty, the Maiki Hill flagstaff entered a period of controversy and incident. In 1976 it was said to resemble the leaning Tower of Pisa after supporting chains were cut by vandals. ${ }^{62}$ Two years later Whakakotahitanga fell victim to the natural elements when the top section of the pole was shattered by lightning. It was 
replaced by a five-metre fibreglass sleeve, which was lowered into place with the help of a helicopter. One of those responsible for overseeing the job explained that the decision to proceed in this manner, rather than bringing down the whole flagpole was in part due to wariness about the tapu placed on the flagstaff at the time it had first been raised in $1858 .{ }^{63}$

With full road access up to and beyond the flagstaff now in place, the development of its surrounds became viable. In 1971 the subdivision of a large area immediately below the flagstaff on Titore Way was approved. In 1976 no dwellings had yet been erected and just four of the lots had been sold by the developer. A Russell Working Party formed to consider future town-planning issues resolved that year to urge that the subdivision instead be designated a proposed reserve ${ }^{64}$ By the following year, the owner of the unsold lots was anxious to learn whether the government was indeed intending to follow through with this recommendation. The Bay of Islands County Council, which had superseded the Russell Town Board, advised the owner that it was unaware of any reserve proposal. ${ }^{65}$ The area in question had been zoned residential under the operative district scheme and was included within the Russell Historic Protection Zone. To erect any buildings within the area an application was therefore required under section 30B of the Town and Country Planning Act 1953, which required the application to be publicly advertised so that any objections could be called for and received. At the same time, the owner was reassured that it was 'not the intention of the zoning to prohibit the erection of houses along Titore Way', but merely to ensure that these complied with conditions requiring dark colouring and landscaping. ${ }^{66}$ Remarkably, given that the erection of up to 23 houses immediately below the flagstaff was being proposed, there was no reference at all to the impact of this development upon Maiki Hill and the flagstaff itself.

The Commissioner of Crown Lands in Auckland meanwhile informed the owner late in 1977 that he personally 'believed it would be environmentally unfortunate if the sections were built upon but I knew that it was an approved subdivision, the land is zoned residential, and the local authority really had no option but to grant building permits as things stand at present'. The owner's suspicions that the Crown was secretly planning to designate the sections for reserve purposes were assuaged somewhat when the possible purchase of these at full market value was mentioned as a possibility ${ }^{67}$

At least the Commissioner of Crown Lands had some concern for the impact of the proposed development on Whakakotahitanga. With the owners preparing to sell the remaining sections, in January 1978 he travelled to the Bay of Islands to meet with them. According to his subsequent file note:

I expressed the personal view ... that the subdivision in the Titore Way area was most unfortunate and that it would have environmental effects 
which were severe. I drew attention to the likelihood of the vista from the Flagstaff Reserve, a spot where thousands of tourists go, being very seriously compromised. The thought of houses, let alone backyards, clotheslines, cars etc. immediately below was somewhat disconcerting. I expressed the view that although the subdivision had been approved by the local body some years back, it is unlikely that in this day and age it would now be approved. Certainly the environmental effects would be much more closely considered by the local body and by Government agencies who might become aware of the proposal. I also said I thought that the public itself would express adverse comment upon such a subdivision and indeed some members of the public are likely to start expressing concern if houses are commenced on the existing subdivision. ${ }^{68}$

The previous sale of some of the sections complicated the potential Crown purchase of the area, but the Commissioner expressed his view that it would be an environmental disaster... if the subdivision became built up immediately below the Flagstaff Reserve'.

With the owner pressing for a quick Crown decision as to whether it intended proceeding with the purchase of the subdivision, by early March 1978 a visual and environmental impact report had been commissioned and completed on the proposed housing development. That report, completed by D.L. Marchant, a landscape architect, considered three possible options for the area: full development; partial development in which only the most critical areas were protected through Crown purchase; and no development. The author concluded that "either full or partial housing development... would severely jeopardise the special scenic and historic qualities that afford Russell its importance as a historic place of both regional and national importance'. He urged the Crown to 'initiate a positive course of action to protect the existing character of Maiki Hill from adverse developments'. ${ }^{69}$

This unequivocal report sparked an equally unequivocal response, though not the one that might have been expected. The Commissioner of Crown Lands noted shortly after the report had been released that 'this is a very difficult matter and one which, if we do not go the right way, could be extremely embarrassing to the Department later on if there is any environmental outcry against the erection of houses on the sections. I believe there will be such an outcry. ${ }^{70}$ His memorandum was, however, written in the knowledge that the government had indeed decided not to go the right way. Already it had been decided at a ministerial level that 'because of the financial situation and also because of the number of owners now in the subdivision and also because of the Minister's concern over further largescale designations, the matter was not to be taken any further' ${ }^{71}$ There was, in other words, to be no attempt to purchase the sections or to designate 
the land as a proposed reserve. With the decision now apparently made at ministerial level not to block the housing development, the Commissioner of Crown Lands advised the Bay of Islands County Council that he was prepared to make staff available to assist in 'determining in what way building permit approvals can be conditioned to ensure a minimum of environmental detraction when viewed from the important Flagstaff Hill Lookout'. ${ }^{72}$ Yet the government's own report had stated in categorical terms that any housing development would have significant and unacceptable detrimental impacts upon Maiki Hill and its surrounds. When Maihi Paraone Kawiti had urged the Crown in the 1870s to 'clothe' Whakakotahitanga he probably did not mean with Pakeha houses.

Looking back on the debate in the 1970s, two themes emerge. Firstly, Maori voices were neither heard nor apparently solicited by either local or central government officials in considering the impact of housing upon Maiki Hill. There appears to have been no consultation at all with tangata whenua, and while Kororareka Maori had been deprived of their last remaining lands in the township as long ago as the 1860s, local hapu retained strong associations with the area, and especially with Maiki Hill and the Whakakotahitanga flagstaff. Indeed, their long-running efforts to establish a marae in the township highlighted the depth of their attachment.

Secondly, the debate largely centred on the visual impact of housing development, especially on the views tourists would have from the flagstaff, and on whether these might be impeded in any way; the impact on the flagstaff itself barely figured. At no point was there any acknowledgement that the site was a tapu one of great significance for all northern Maori. Those sorts of considerations simply did not appear to enter the equation at the time.

The flagstaff meanwhile suffered further acts of vandalism, some of it politically motivated. Indeed, like the lone pine on One Tree Hill, the flagstaff became the victim of many striking but bloodless acts of protest that can perhaps be seen as part of a 'Hone Heke tradition'. ${ }^{73}$ Whakakotahitanga was felled twice in the space of less than six months in 1981 - the first time, it was rumoured, by anti-apartheid protestors following speculation that the Springbok rugby team would spend two days at the Bay of Islands. ${ }^{74}$ The felling prompted the warning from kaumatua Sir James Henare that the flagstaff was tapu and that anybody who sought to fell it must consider the consequences. Despite Henare's declaration, in 1983 an early morning explosion whose blast was felt for three kilometres marked an attempt to blow up the flagstaff. Maori protestors were this time suspected - 'the Treaty of Waitangi is a fraud' having been scribbled at the flagstaff's base. ${ }^{75}$ Somewhat remarkably, although sticks of gelignite had been strapped to both sides of its base, the flagstaff itself was not felled, but hung precariously in the air, 
supported by two of the four chain supports installed after Whakakotahitanga had been attacked by vandals three times over the previous 18 months. It was subsequently removed by Ministry of Works staff in order to allow the heavily shattered concrete base to be replaced. ${ }^{76}$

More than a century of neglect and abuse had left Whakakotahitanga in a near terminal state, and in 1991 a preliminary assessment concluded that the flagstaff was beyond repair. That conclusion, based on initial Navy and Department of Conservation inspections, was shared by the descendants of Heke and Kawiti. They were concerned that rotting near the base of the flagstaff - a legacy of repairs undertaken after the first attack on it in 1954 - left the pole in a dangerous condition and that all it might take to precipitate a disaster would be for children to swing on the supporting chains. ${ }^{77}$ While a meeting of interested parties held immediately underneath Whakakotahitanga resolved that it should be replaced, according to a later manuscript prepared by Ted Jones of the Department of Conservation, 'the most important aspect of the meeting to Kaumatua was not the replacement but in fact what was to be the fate of the old flagstaff' ${ }^{78}$

On 27 February the following year, Whakakotahitanga bowed its head once again - most people now assumed for the final time. Descendants of Hone Heke, Kawiti and others announced their intention to remove the remains of the flagstaff to the Kawiti family marae, where it would be received, they explained, in a similar manner to the return of a body - with tears, feasting and speeches directed at Whakakotahitanga. ${ }^{79}$ Before the removal could take place, there had been a huge groundswell of renewed interest in the flagstaff, and luckily closer inspection revealed that the pou kara was not as sick as first feared.

Ringa Witehira, a descendant of Hone Heke, drove the hydraulic excavator used to lift the flagstaff from its steel-socketed base. Ministers performed karakia throughout the extraction, though as Jones later wrote:

To begin with, the flagstaff would not lift out of the socket. The kuia and women were calling and finally it let go and popped out. As the flagstaff was lowered to the ground the men present rushed forward to carry the taonga down the hill to the road. Here it was put on a trailer normally used to carry a waka and slowly driven down to Matuawhi Bay to the Department of Conservation Workshop. More ceremony welcomed the Poukara onto the workshop and placed it in the care of the Department. ${ }^{80}$

Dene Whiting of the Historic Places Trust, the country's only trained wood conservator, was asked to assess the health of Whakakotahitanga and determine whether it could be repaired. He concluded that the area of decay was not as serious as initially thought. While a search began for 
suitable kauri with which to undertake repairs, Whakakotahitanga remained at the Department of Conservation's Matauwhi Bay workshop. Soon after, local kaumatua and other interested parties decided that the flagstaff should instead be displayed at the Russell Museum. Here it attracted many visitors, especially during the periods in which Dene Whiting was working on it. ${ }^{81}$

After a long and frustrating search, a kauri log found lying in the grounds of nearby Pompallier House was eventually identified as suitable for the necessary repairs. It first needed to undergo a lengthy drying process carried out over many weeks in order to match the moisture content of the original wood in the flagstaff. Dean Cook, a descendant of the carpenter who had shaped the original kauri log into a flagstaff on Kororareka Beach in 1857, was one of those who assisted with stripping and repainting it. As further work on the fibreglass cap and rigging was underway, discussion also commenced as to whether a new plaque should replace the one first unveiled in 1930. There was no consensus on this issue, and it was eventually decided that the current plaque should remain, with the option for a new one to be installed at a future date if there was agreement on this amongst Ngapuhi. ${ }^{82}$

After a year of intensive repair efforts the flagstaff was re-erected on 20 March 1993. That date had been specially chosen as the anniversary of the selection by northern rangatira of the first national flag - a flag hoisted upon Whakakotahitanga on 12 days each year, each representing the anniversary of important occasions, such as the Declaration of Independence and Treaty of Waitangi signings, the deaths of Heke and Kawiti and various Northern War battles. ${ }^{83}$

Planning for the event was complicated by the lack of a marae in Russell. A temporary one was designated on a school playing field in the township, and many other marae, businesses and volunteers, along with the New Zealand Army, offered their assistance for the occasion. Large numbers of visitors arrived in town on the eve of the ceremony. ${ }^{84}$ Meanwhile, the summit of Maiki Hill was declared tapu as workers prepared for the return home of Whakakotahitanga, and Maori wardens guarded the site. In the early hours of 20 March 1993, kuia waited to karanga the flagstaff on. Upon its arrival, speeches were made, and an initial problem with the fibreglass potae eventually resolved. Department of Conservation workers then noticed that the yardarm was not facing the car park as planned, and were contemplating lifting the flagstaff out to correct this when kaumatua Jim King declared that it was facing the right way: it was directly facing Waitangi. Shortly before dawn, after blessings were completed, the flag of the Confederation of United Tribes was unfurled. A guard of honour from the navy and army dressed in full uniform and with fixed bayonets held vigil until sunrise. Whakakotahitanga was home again. ${ }^{85}$ 
Prior to the ceremony itself, the flagstaff was officially returned to local Maori, who passed it to the guardianship of the Department of Conservation and confirmed their desire to see Whakakotahitanga again stand upon Maiki Hill. ${ }^{86}$ Just as in 1858 , it became their decision to erect the flagstaff, which remains not as a symbol of Crown sovereignty but as a solemn reminder of the aspirations of their tupuna. One rangatira had years earlier described the flagstaff as 'a living thing' ${ }^{87}$ Seen in those terms, the life history of Whakakotahitanga mirrors the broader Treaty relationship in many respects. After the initial high hopes and expectations, contrary assumptions and veiled fears, a long period of neglect ensued, followed in more recent times by controversy, renewed interest and ultimately perhaps a certain enhanced appreciation of its place in New Zealand history. However, Whakakotahitanga remains subject to occasional acts of vandalism, and encroaching tourism developments constitute a continuing threat. ${ }^{88}$ Remarkably, this site of outstanding historical and cultural significance is not (at the time of writing) registered under the Historic Places Act. It remains under the administration of the Department of Conservation.

Although the 1992 decision to re-erect the flagstaff was partly motivated by a desire to use Whakakotahitanga as a symbol of local Maori plans to re-establish a marae in the town, those efforts continue to be beset by difficulties in obtaining resource consents and other obstacles. ${ }^{89}$ The establishment of such a marae would at least be one small step towards achieving the objectives of those who erected Whakakotahitanga in 1858, and the return of the land upon which the flagstaff sits to tangata whenua would be another. For above all else, Whakakotahitanga remains as a testament to the notion that there were many significant agreements between the government and Maori besides the Treaty of Waitangi, and these other agreements may have physical symbols that survive to the present, all the more important because their texts have not. ${ }^{90}$ In this respect, Whakakotahitanga stands as a silent yet resonant reminder of the aspirations of those northern tribes who solemnly renewed their relationship with the Crown some 150 years ago.

1 See James Belich, The New Zealand Wars and the Victorian Interpretation of Racial Conflict, Auckland, 1986; James Cowan, The New Zealand Wars: A History of the Maori Campaigns and the Pioneering Period, 2 vols, Wellington, 1983, I; and T. Lindsay Buick, New Zealand's First War: The Rebellion of Hone Heke, Wellington, 1926.

2 George Clarke [Jnr], Notes on Early Life in New Zealand, Hobart, 1903, p.92.

3 On the government's inability to fully enforce English law in the north in the wake of the Northern War, see Vincent O'Malley, 'English Law and the Maori Response: A Case Study from the Runanga System in Northland, 1861-65', Journal of the Polynesian Society, 116, 1 (2007), pp.7-33.

4 Williams to Marsh, 28 May 1846, cit. Belich, New Zealand Wars, p.70. 


\section{Journal of New Zealand Studies}

5 Officer Commanding Troops at the Bay of Islands to Officer Commanding the Troops at Auckland, 9 February 1846, IA 1/1846/403, Archives New Zealand (ANZ), Wellington.

6 Ian Wards, The Shadow of the Land: A Study of British Policy and Racial Conflict in New Zealand 1832-1852, Wellington, 1968, p.207.

7 Wynard to Colonial Secretary, 12 February 1858, IA 1/1846/403, ANZ.

8 Wards, p.207.

9 Grant Phillipson, 'Bay of Islands Maori and the Crown, 1793-1853', report commissioned by the Crown Forestry Rental Trust, 2005, p.315. See also Marshall Sahlins, Islands of History, Chicago, 1985, pp.60-71. Sahlins suggests the flagstaff was viewed by northern Maori as a tuahu or sacred shrine, the establishment of which was also seen as consistent with a claim to the land itself.

10 Patience to Colonial Secretary, 25 September 1847, IA 1/1848/243, ANZ.

11 Bridge to Colonial Secretary, 2 November 1847, IA 1/1848/243, ANZ.

12 Bridge to Colonial Secretary, 29 January 1848, IA 1/1848/243, ANZ.

13 Sinclair (Colonial Secretary), minute, 15 February 1848, IA 1/1848/243, ANZ.

14 Wynard to Browne, 10 September 1855, 12 September 1855, Great Britain Parliamentary Papers (GBPP), 1860 (2719), 10, pp.153-6; IA 1/1856/3267, ANZ.

15 Clendon to McLean, 8 August 1857, McLean Papers, MS Papers 0032, Alexander Turnbull Library (ATL), Wellington; McLean Papers, typescript, XIV, MS Papers 1319, ATL.

16 New Zealand Parliamentary Debates (NZPD), 1858, 1856-1858, p.519.

17 Appendices to the Journals of the House of Representatives (AJHR), 1862, E-7, pp.16-17; AJHR, 1862, E-7, p.20.

18 Henry Williams, Annual Report , 1857, CN/06, Micro-MS-Coll-4-44, ATL.

19 Tawhai to the Governor, 31 July 1857, BAVX 4817/5a, Archives New Zealand (ANZ (Akl)), Auckland.

20 M.P. Kawiti, Letter to Editor, 18 January 1858, Te Whetu o Te Tau (WT), 1 July 1858.

21 Kawiti to Native Minister, 23 May 1887, MA 13/80, ANZ.

22 Bolger to Auckland Superintendent, 19 November 1857, IA 1/1857/1699, ANZ.

23 McLean, marginal notes on Superintendent to Colonial Secretary, 25 November 1857, IA 1/1857/1699, ANZ; McLean to Resident Magistrate, Bay of Islands, 16 December 1857, MA 4/2, ANZ.

24 Te Karere Maori (TKM), 31 October 1857.

25 White to Colonial Treasurer, 13 October 1857, IA 1/1857/1699, ANZ.

26 C.W. Richmond, marginal note on White to Colonial Treasurer, 6 January 1858, IA $1 / 1858 / 140$, ANZ.

27 T.H. Smith, marginal note on White to Colonial Treasurer, 25 January 1858, IA 1/1858/140, ANZ.

28 Marginal note, 28 January 1858, IA 1/1858/140, ANZ; Smith to White, 11 February 1858, MA 4/2, ANZ. The new Mangonui flagstaff, christened Victoria and Albert by local rangatira, was unveiled for the first time on 2 February 1858. TKM, 27 February 1858.

29 TKM, 15 January 1858.

30 TKM, 15 May 1858.

31 Kawiti to the Governor, 9 April 1888, MA 13/80, ANZ.

32 Browne to McLean, n.d. [c.8 February 1858], McLean Papers, MS Papers 0032, ATL. 
33 Browne to McLean, n.d. [c.30 January 1858], McLean Papers, MS Papers 0032, ATL.

34 Smith to Resident Magistrate, Bay of Islands, 23 March 1858, MA 4/2, ANZ.

35 Heke to Queen Victoria, 10 July 1849, GBPP, 1850 (1280), 6, pp.17-18.

36 TKM, February 1858.

37 Stanley to Gore Browne, 27 May 1858, reproduced in TKM, 31 August 1858.

38 TKM, 14 July 1860.

39 Barstow to Civil Commissioner, 27 April 1863, BAVX 4815/1a, ANZ (Akl).

40 Gisborne to Resident Magistrate, Russell, 1 May 1863, BAVX 4817/24b, ANZ (Ak1).

41 William Fox, memorandum by ministers, 30 September 1864, AJHR, 1864, E-1, pp.50-2.

42 Daily Southern Cross (DSC), 22 March 1873.

43 Kawiti to the Governor, 9 April 1888, MA 13/80, ANZ.

44 Evening Post (EP), 25 February 1913.

45 Heather Lindauer, 'The Survivor', Russell Review (RR), 2005, pp.7-8.

46 The plaque had been donated by H. Morpeth of Auckland, Russell Town Board Minute Books, 1929-1935, p.15, Far North District Council Archives (FNDCA), Kaikohe.

47 Ibid., p.20.

48 Ibid.; New Zealand Herald (NZH), 12 April 1930.

49 Commissioner of Crown Lands to Under Secretary for Lands, 24 February 1939, BAAZ 1109/814a pt.1, ANZ (Akl).

50 Resident Engineer to Senior Engineer, Public Works Department, 12 July 1948, ZACE 14959/62a, ANZ (Akl).

51 Senior Engineer to Resident Engineer, Whangarei, 27 August 1948, ZACE 14959/62a, ANZ (Akl).

52 Ibid.

53 Director-General to Commissioner of Crown Lands, Auckland, 23 March 1953, BAAZ 1109/814a pt.1, ANZ (Akl).

54 Commissioner of Crown Lands, Auckland, to Director-General, 7 May 1953, BAAZ 1109/814a pt.1, ANZ (Akl).

55 Commissioner of Crown Lands, Auckland, to Director-General, 3 December 1953, BAAZ 1109/814a pt.1, ANZ (Akl).

56 Commissioner of Crown Lands, Auckland, to Town Clerk, Russell Town Board, 22 December 1953, BAAZ 1109/814a pt.1, ANZ (Akl).

57 NZH, 8 February 1954.

58 Commissioner of Crown Lands, Auckland, to District Commissioner of Works, 11 July 1955, BBAD 1054 50/22/300 pt.1, ANZ (Akl).

59 District Commissioner of Works to Resident Engineer, Whangarei, 13 July 1959, BBAD 1054 50/22/300 pt.1, ANZ (Akl).

60 Auckland Star (AS), 14 August 1973; Northern Advocate (NA), 14 August 1973.

61 Ibid.

62 NZH, 31 August 1976.

63 Northern Advocate (NA), 7 September 1978.

64 Senior Planning Officer to Commissioner of Crown Lands, Auckland, 8 July 1976, BBEE 15336 1/9/13/22, ANZ (Akl).

65 Planning Officer to Commissioner of Crown Lands, Auckland, 4 July 1977, BBEE 15336 1/9/13/22, ANZ (Akl). 


\section{Journal of New Zealand Studies}

66 Planning Officer to Fladgate, 22 July 1977, BBEE 15336 1/9/13/22, ANZ (Akl).

67 Commissioner of Crown Lands, Auckland, File Note, 12 December 1977, BBEE 15336 1/9/13/22, ANZ (Akl).

68 Commissioner of Crown Lands, Auckland, File Note, 31 January 1978, BBEE 15336 1/9/13/22, ANZ (Akl).

69 The Fladgate Subdivision Russell: A Visual and Environmental Impact Assessment, BBEE 15336 1/9/13/22, ANZ (Akl).

70 Commissioner of Crown Lands, File Note, 20 March 1978, BBEE 15336 1/9/13/22, ANZ (Akl).

71 Ibid.

72 Commissioner of Crown Lands, Auckland, to General Manager, Bay of Islands County Council, 21 March 1978, BBEE 15336 1/9/13/22, ANZ (Akl).

73 I am indebted to an anonymous reviewer for this observation.

74 NZH, 27 August 1981, 22 December 1981.

75 NA, 28 February 1983.

76 Ibid.

77 NA, 11 December 1991.

78 Ted Jones, 'Refurbishing the Flagstaff/Poukara E Whakakotahi Tanga', unpublished manuscript, Department of Conservation, 1993. An abridged version of this manuscript was later published. See Ted Jones, 'Whakakotahitanga: The Refurbishing of the Flagstaff', Russell Review, 1993-1994, pp.52-59.

79 NZH, 24 January 1992.

80 Jones, 'Refurbishing', n.p.

81 Ibid.

82 Ibid.

83 NA, 1 February 2007; Lindauer, p.8; Claudia Orange, The Treaty of Waitangi, Wellington, 1987, p.20.

84 Jones, 'Refurbishing', n.p.

85 Ibid.

86 Ibid.; Northern News (NN), 25 March 1993.

87 NZH, 24 January 1992.

88 NA, 1 February 2007; BBEE 15333/486, ANZ (Akl). A further major restoration project was completed by the Department of Conservation in December 2007. Bay Chronicle (BC), 27 December 2007.

89 Joris de Bres, 'Public Meeting on the Kororareka Marae Society Proposal for a Community Marae in Russell, Russell Town Hall, 8 September 2006', Race Relations Commission Report, accessed 9 February 2008 at: http://www.hrc.co.nz/hrc new/hrc/cms/files/documents/22-Sep-2006_13-27-02_Public_Meeting_on_the_Proposal_ for_a_Community_Marae_in_Russell.doc.

90 Acknowledgement is due to an anonymous reviewer for bringing this point to my attention. See James Belich, Making Peoples: A History of the New Zealanders from Polynesian Settlement to the End of the Nineteenth Century, Auckland, 1996, pp.202-3; R.P. Boast, 'Recognising Multi-Textualism: Rethinking New Zealand's Legal History', Victoria University of Wellington Law Review, 37, 4 (2006), pp.547-82; and Vincent O'Malley, 'Treaty-Making in Early Colonial New Zealand', New Zealand Journal of History, 33, 2 (1999), pp.137-54. 